\title{
Global Shift
}

\section{- Salvador Santino F. Regilme}

- Henrik S. Hartmann

\section{This is the preprint version.}

Cite this entry as:

Regilme S.S.F., Hartmann H.S. (2019) Global Shift. In: Romaniuk S., Thapa

M., Marton P. (eds) The Palgrave Encyclopedia of Global Security Studies.

Palgrave Macmillan, Cham

Living reference work entry

First Online: 01 November 2019

DOI: https://doi.org/10.1007/978-3-319-74336-3 53-2

Key Words: Emerging powers; Geopolitics; Hegemony; Power politics

\section{Introduction}

Global shift refers to the transformative, transitionary, aggregate, and multidimensional processes whereby a state, or a group of states, actively and strategically challenges the dominant power position of a status quo global hegemon or a leading group of states. Through dominance in the military and economic realms as well as in ideology, a status quo power is able to act as a global hegemon. A global hegemon has the power to effectively establish and maintain a global order of rules, norms, and institutions which govern, to a certain extent, world politics and the interaction of states, markets, and transnational civil society.

Three states are considered as having successfully established global hegemony over a certain period of time in the so-called 'modern' era since the $15^{\text {th }}$ century: the Kingdom of the Netherlands, the United Kingdom, and the United States of America (US) (Wallerstein, 2004, p. 57). However, hegemonies, at least over regional spheres, have been established and subsequently challenged for millennia, ranging from the Roman Empire $\left(1^{\text {st }}\right.$ century BC $-5^{\text {th }}$ century AD) in the Mediterranean to the Mongol Empire $\left(13^{\text {th }}-14^{\text {th }}\right.$ century AD) in Central Asia or the Umayyad Caliphate $\left(7^{\text {th }}-8^{\text {th }}\right.$ century $\mathrm{AD})$ in the Middle East.

The most recent global hegemon has been the US from the mid- $20^{\text {th }}$ century on, albeit its hegemony has been subject to processes of global shift in the past decade. The contemporary global order, established in the immediate aftermath of the Second World War, is marked by the post-war dominance of the US, even though important veto powers in the Security Council of the United Nations were granted to regional victorious powers: France, the United Kingdom, the Union of Soviet Socialist Republics (USSR) and the Republic of China. 
In fact, the US hosts all three main global institutions on its territory: the United Nations Headquarters in New York, the World Bank, and the International Monetary Fund (IMF) in Washington D.C. Furthermore, the US Dollar effectively served as global reference currency under the Bretton Woods System until the 1970s, as other currencies fixed their exchange rate to the US Dollar, its value being in turn attached to the value of gold. Since the Second World War, the US has been thus far the largest economy (United Nations, 2017) and the largest military spender worldwide (Singer, Bremer, \& Stuckey, 1972) - although China has recently overtaken the US by certain measures, particularly in terms of Gross Domestic Product (GDP) at purchasing power parity (Smith, 2017). Last but not least, the US had been highly influential in terms of exporting American culture and business to countries across the globe, a process often described as 'Americanization' (Beck, Sznaider, \& Winter, 2013).

\section{Processes of Global Shift}

The processes of global shift (military, economic, and ideological) generally occur over a relatively long-term period, thus rendering the effective dissolution of global hegemony a gradually erosive process. Furthermore, the processes of global shift tend to be accumulative, since the economy can present an enabling and catalyzing element for the military and ideological processes. Given the historic scarcity of truly global hegemonies, processes of global shift are generally only partially successful, by dismembering global hegemony into several regional hegemonies, rather than replacing global hegemony. Instead of maintaining unipolarity then, processes of global shift render world politics into a multipolar or, on rare occasions, into a bipolar affair.

\section{Global Military and Economic Shifts}

In the military realm, the hegemony of the US remains thoroughly intact as far as gross military spending is concerned, given that the US outspent its eight closest competitors in 2016 (SIPRI, 2018). Nonetheless, indications of an ongoing global shift can be observed in the early $21^{\text {st }}$ century, since the Asian continent has largely bypassed Northwestern Europe as the second regional military power. While the People's Republic of China (China) solidified its position as second global military might in 2016, Saudi Arabia, Russia, India, Japan and South Korea equally continued their military buildup (SIPRI, 2018).

However, recent patterns of global shift in military spending are yet to affect the contemporary hierarchy and asymmetry of military capabilities among countries worldwide. Despite the Chinese investments of the past years, the Russian Federation (Russia) remains the second most capable military power, especially with regard to aerial and armored warfare (IISS, 2017). Furthermore, China remains to date relatively insignificant in terms of global military presence, holding only one foreign military base in Djibouti. In contrast, Russia currently holds nine foreign military bases, while France and the United Kingdom each have eleven bases. As for the US, 
its military presence extends to as many as 40 countries across the globe (SIPER, 2016).

In terms of nuclear capabilities, the process of global military shift seems to advance at considerably slower pace than in terms of military spending and non-nuclear capabilities. Despite the Treaty on the Non-Proliferation of Nuclear Weapons of 1970, nuclear weapons did proliferate from the US to the USSR, the United Kingdom, France, China, India, Pakistan and North Korea between the 1940s and 2000s. While nuclear proliferation does constitute an ongoing global shift, Russia and the US remain the dominant nuclear powers, constituting together some 92 percent of the global nuclear arsenal (Kristensen \& Norris, 2017).

The direction and pace of the ongoing global military shift is most notably conditioned by global economic shifts. In fact, economic growth rates of China and India did slow down over the past five years, albeit not to similarly low levels as in Northwestern Europe (World Bank, 2017). Nonetheless, the future pace of Chinese military buildup appears resistant to the slight economic slowdown, as less than two percent of China's GDP was allocated to defense spending in 2015. This compares to over three percent in the US, over five percent in Russia and over 13 percent in Saudi Arabia, the other leading military spenders worldwide (SIPRI, 2017).

The rapid economic growth in so-called 'emerging' economies in the late $20^{\text {th }}$ and early $21^{\text {st }}$ centuries led to the creation of new concepts about the prospects of economic growth and the implications thereof on the global economic order. In 2001, the 'BRIC' acronym was first established, as Brazil, Russia, India and China then constituted a fourth of the global GDP (O'Neill, 2001). In 2010, the four countries established a formal institution while approving the accession of South Africa to form the BRICS (Smith, 2011). In 2014, BRICS founded the New Development Bank with seat in Shanghai, portrayed as an alternative to the US-led economic order under the IMF and the World Bank (BRICS, 2014).

While the BRICS institution did not yet fundamentally alter the global order, global economic shift is expected to continue. In 2022, one third of global GDP will be generated by BRICS, compared to one fourth by the Group of Seven (G7): Canada, France, Germany, Italy, Japan, the United Kingdom and the US (IMF, 2017). Considering the demographic weight of emerging economies in the G20, global shift within the institutions of the contemporary global order, at the expense of G7 countries, appears to be merely a matter of time.

\section{Global Ideological Shifts}

The main ideological contender throughout most of contemporary US hegemony has been Communism, primarily embodied by the USSR, China, Cuba, North Korea and Vietnam. The Cold War demonstrated the interconnectedness of the ideological, military, and economic spheres, as the parties to the Cold War equally engaged in several hot 'proxy' wars over geopolitical considerations. Both the Western and Eastern Bloc established independent regional institutions, most notably in the military and economic realms. Nonetheless, both sides were part of the United 
Nations and its Security Council, thus making a considerably more global order than the League of Nations, established after the First World War (Lipscy, 2017).

Some scholars, most notably Francis Fukuyama, interpret the end of the Cold War as "the end point of mankind's ideological evolution and the universalization of Western liberal democracy" (Fukuyama, 1989, p.4). For a certain period in the 1990s and early 2000 s, ideological alternatives to US hegemony did indeed seem to have been exhausted over the course of the "short $20^{\text {th }}$ century" (Hobsbawm, 1995, p.3). However, the early $21^{\text {st }}$ century witnessed a quick "return of history," (Kagan, 2007) as Russia and China assumed increasingly important roles in regional and world politics whilst differentiating themselves discursively from US foreign policy (Lo, 2008).

Furthermore, non-state actors grew considerably in perceived global importance following the terrorist attacks on the World Trade Center in New York and the US Department of Defense Headquarters in Virginia on 11 September 2001. Over fifteen years after the US declared the "war on terrorism," (The White House, 2001) armed Islamic terrorism is far from being eradicated, despite several intensified military interventions by the US in the Greater Middle East. In fact, Iraq and Afghanistan remained the most detrimentally affected by terrorism in 2016, accounting for half of all worldwide deaths from terrorism (IEP, 2017, p.16). The three deadliest terrorist groups of 2016, the Islamic State of Iraq and the Levant, the Taliban and Al-Qa'ida, have all been discursively promulgating anti-Western worldviews (Glenn, 2015).

In addition to these patterns of emerging global ideological shifts, recent years witnessed an increase in 'anti-globalization' sentiments in the US and Europe, the heartland of the contemporary global order. Left-wing 'anti-globalization' is aimed against the dominance of neoliberalism within the institutions of the US-led global order and the political power that multinational corporations are able to wield (Johnson, 2009). In contrast, right-wing 'anti-globalization' seeks to recapture national sovereignty from multilateral institutions while primarily mobilizing popular grievances related to issues of immigration (Ivarsflaten, 2008).

\section{Conclusion}

US claim for global dominance is currently under siege both within and beyond its territories. Domestically, the presidency of Donald Trump activated racist, sexist, and crude nationalist discourses and policy strategies in mainstream American politics. At the international level, longstanding allies of the US, including those in Europe and the Asia-Pacific region, have begun to question whether Washington could still remain a reliable ally amidst rising powers such as Russia and China, both of which represent a distinctive ideological flag and mode of governance. Empowered by the rhetoric of human rights, liberal democracy, and market-oriented capitalism backed by the use of military force in the way of enduring American expansionist policy strategies, the US under the Trump presidency appears to be a status quo dominant power that is currently facing serious legitimation problems, domestically and internationally. Amidst such a legitimation crisis, rising and reemerging powers such 
as Brazil, Russia, India, Iran, China, South Africa, Turkey, among many others continue to contest, if not unconditionally limit, US power in their respective worldregions. Those developments pose uncertainty especially after racist, sexist and antiliberal democratic political parties and politicians have recently gained traction in several critical regions of the world - an outcome that undermines the ideological underpinnings of US dominance hinged upon human rights, democracy, and rule of law and supported by rich and liberal democratic allies in the West.

Overall, those aforementioned developments pose several concerns regarding the notion of global shift. The mainstream literature often invokes the inevitability of large-scale interstate war as a result of the escalating rivalry between status quo and challenging powers (Mearsheimer, 2006). Yet, global shifts do not happen merely because of imbalances in material factors - such as military and economic resources - but also whether the challenging powers are ideologically constructed as fundamentally antithetical to the core identity, values, and interests of the status quo power (Regilme \& Parisot, 2018; Bridoux 2018; van de Wetering, 2018). Finally, another potentially significant cause of a global shift is material inequality not only between but, perhaps more importantly within nations. Such a situation emerges when domestic instability is fueled by the dramatic decline of public goods provision, equitable economic growth, and scandalous levels of material inequality (Regilme, 2014; Piketty, 2014). To the extent that the legitimacy of US hegemony depends upon the enduring stability of liberal democratic systems over alternative forms of governance that rising and reemerging powers might offer, the potential regress and eventual decay of consolidated and new democratic regimes could gravely undermine future US power, thereby escalating a wider global shift.

\section{Salvador Santino F. Regilme Jr. \& Henrik S. Hartmann Leiden University, Leiden, The Netherlands}

See also Balance of Power; Brazil, Russia, India, China and South Africa (BRICS); Emerging Powers; Geopolitics; Global Threats; Ideology; International Monetary Fund; Neoliberalism; Nuclear Proliferation; North Atlantic Treaty Organization (NATO); Post-Cold War Environment; Terrorism; United Nations Security Council; "War on Terror"; World Bank

\section{References}

BRICS. (2014). Agreement on the New Development Bank. Retrieved from http://brics.itamaraty.gov.br/agreements Institute for Economics and Peace. (2017). Global terror- ism index 2017. Retrieved from http://visionof humanity.org/app/uploads/2017/11/Global-Terrorism- 
International Institute for Strategic Studies. (2017). The military balance 2017. Retrieved from http://www. iiss.org/en/publications/military\%20balance/issues/the- militarybalance-2017-b47b

International Monetary Fund. (2017). World economic out- look database, October 2017. Retrieved from http:// www.imf.org/external/pubs/ft/weo/2017/02/weodata/ download.aspx

Kristensen, H., \& Norris, R. (2017). Status of world nuclear forces. Federation of American Scientists. Retrieved from https://fas.org/issues/nuclear-weapons/ status-worldnuclear-forces/

Singer, J. D., Bremer, S., \& Stuckey, J. (1972). Capability distribution, uncertainty, and major power war, 1820-1965. International Interactions, 14, 115-132. Retrieved from http://cow.dss.ucdavis.edu/data-sets/ national-material-capabilities

Smith, N. (2017). Who has the world's no. 1 economy? Not the U.S. Bloomberg. Retrieved from https://www. bloomberg.com/view/articles/2017-10-18/who-has-the- world-s-no1-economy-not-the-u-s

Stockholm International Peace Research Institute. (2018). SIPRI military expenditure database. Retrieved from https://www.sipri.org/databases/milex

Swiss Institute for Peace and Energy Research. (2016). Military bases of the US; of Russia; of France; of the UK; of China. Retrieved from https://www.siper.ch/en/ peace/infographs/

Swiss Institute for Peace and Energy Research. (2017). Trends in World Military Expenditure, 2017. Retrieved from https://www.sipri.org/sites/default/files/2018-04/ sipri_fs 1805 milex_2017.pdf

The White House. (2001). Remarks by the President upon arrival. Retrieved from https://georgewbush-white house.archives.gov/news/releases/2001/09/20010916-2. $\underline{\mathrm{html}}$

United Nations. (2017). National accounts main aggre- gates database. Retrieved from https://unstats.un.org/ unsd/snaama/dnllist.asp

World Bank. (2017). GDP growth (annual \%). Retrieved from https://data.worldbank.org/indicator/NY.GDP. MKTP.KD.ZG

Further Reading

Beck, U., Sznaider, N., \& Winter, R. eds. (2004). Global America? The cultural consequences of globalization. Liverpool: Liverpool University Press.

Bridoux, J. (2018). Stronger than strong: Perceptions and misperceptions of power. In S. S. F. J. Regilme \& J. Parisot (Eds.), American hegemony and the rise of emerging powers. London/New York: Routledge.

Fukuyama, F. (1989). The end of history? The National Interest, 16, 3-18.

Glenn, C. (2015). Al Qaeda v ISIS: Ideology \& strategy. Wilson Center. Retrieved from https://www.wilsoncen ter.org/article/al-qaeda-v-isis-ideology-strategy

Hobsbawm, E. (1995). Age of extremes: The short twenti- eth century, 1914-1991. London: Abacus. 
Ivarsflaten, E. (2008). What unites right-wing populists in Western Europe? Comparative Political Studies, 41(1), 3-23.

Johnson, S. (2009). The quiet coup. The Atantic. Retrieved from https://www.theatlantic.com/magazine/archive/ 2009/05/the-quiet-coup/307364/

Kagan, R. (2007). End of dreams, return of history. Policy Review, 144, 17-44.

Lipscy, P. (2017). The League of Nations and the United Nations Security Council. In Renegotiating the world order: Institutional change in international relations (pp. 200-245). Cambridge: Cambridge University Press. Lo, B. (2008). Axis of convenience. Washington, DC:Brookings Institution Press.

Mearsheimer, J. J. (2006). China's unpeaceful rise. Current History, 105, 160-162.

O’Neill, J. (2001). Building better global economic BRICs. Goldman Sachs Global Economic Paper, 66. Retrieved from http://www.goldmansachs.com/our-thinking/ archive/archive-pdfs/build-better-brics.pdf

Piketty, T. (2014). Capital in the twenty-first century.Cambridge, MA: Harvard University Press.

Regilme, S. S. F. (2013). It takes two to tango: a construc- tivist analysis of EU-ASEAN interregional relations. In Global Power Europe-Vol. 2 (pp. 237-252). Berlin \& Heidelberg: Springer.

Regilme, S. S. F. J. (2014). Bringing the global political economy back in: Neoliberalism, globalization, and democratic consolidation. International Studies Per- spectives, 15(3), 277-296.

Regilme, S. S. F. J. (2018). Beyond Paradigms: Under- standing the South China Sea Dispute Using Analytic Eclecticism. International Studies, 55, 1-25.

Regilme Jr, S. S. F. (2019). The decline of American power and Donald Trump: Reflections on human rights, neo- liberalism, and the world order. Geoforum, 102, 157-166.

Regilme, S. S. F. J., \& Parisot, J. (2017). Introduction: Debating American hegemony Global cooperation and conflict. In S. S. F. J. Regilme \& J. Parisot (Eds.), American hegemony and the rise of emerging powers. Abingdon/New York: Routledge.

Regilme, S. S. F. J., \& Hartmann, H. (2018). Mutual Delegitimization: American and Chinese Development Assistance in Africa. The SAIS Review of International Affairs. Available at: http://www.saisreview.org/2018/ 03/30/china-america-developmentassistance/.

Smith, J. (2011). BRIC becomes BRICS: Changes on the geopolitical chessboard. Foreign Policy Journal. Retrieved from https://www.foreignpolicyjournal. com/2011/01/21/bric-becomes-brics-changes-on-the- geopolitical-chessboard/2/

Van De Wetering, C. (2018). A narrative for cooperation with rising India: An analysis of a US think tank. In S.

S. F. J. Regilme \& J. Parisot (Eds.), American hege- mony and the rise of emerging powers. London/New York: Routledge.

Wallerstein, I. (2004). World systems analysis - An intro- duction. Durham/London: Duke University Press. 